\title{
CHALLENGES IN RADIOCARBON DATING ORGANIC CARBON IN OPAL-RICH MARINE SEDIMENTS
}

\author{
Yan Zheng ${ }^{1,2} \bullet$ Robert F Anderson ${ }^{1}$ Philip N Froelich ${ }^{3} \bullet$ Warren Beck ${ }^{4}$ Ann P McNichol ${ }^{5}$ \\ Thomas Guilderson ${ }^{6}$
}

\begin{abstract}
We explored the reliability of radiocarbon ages obtained on organic carbon phases in opal-rich Southern Ocean sediments. Paired biogenic carbonate and total organic carbon (TOC) ${ }^{14} \mathrm{C}$ analyses for three Southern Ocean cores showed that the TOC ages were systematically younger than the carbonate ages. Carbonate ages were consistent with oxygen isotopic and bio-stratigraphy, indicating error in TOC ages that could be explained by 5-24\% of modern carbon contamination of TOC samples. Two possible sources of contamination are: 1) adsorption of atmospheric $\mathrm{CO}_{2}$ or volatile organic compounds to reactive opal surface sites, and 2) fixation of atmospheric $\mathrm{CO}_{2}$ by chemosynthetic bacteria during core storage. In an effort to reduce the modern carbon contamination, diatoms were separated from sediments, purified, and pre-oxidized by concentrated nitric and perchloric acids to permit dating of opal-intrinsic organic carbon $\left(\sim 0.1-0.3 \%\right.$ by weight). ${ }^{14} \mathrm{C}$ ages of chemically pre-oxidized opal showed a significant amount of modern carbon contamination, from 11 to $32 \%$, indicating adsorption from the atmosphere of modern carbon onto opal surfaces that were previously cleaned by acid oxidation. Several experiments designed to eliminate the modern $\mathrm{C}$ contamination were attempted, but so far we have not been able to obtain a radiocarbon age on ${ }^{14} \mathrm{C}$-dead Southern Ocean opal-rich sediments, either bulk TOC or purified diatom opal samples, as old as our procedural blank.
\end{abstract}

\section{INTRODUCTION}

Radiocarbon dating has proven to be a powerful tool in paleoceanography and paleoclimatology studies. Biogenic carbonate is often used as the carbon phase for establishing ${ }^{14} \mathrm{C}$ chronology. The potential for using marine organic carbon phases in organic carbon-poor $(<1 \%)$ open-ocean sediments is usually unexplored. In regions where production of carbonate is low and/or preservation of carbonate is poor, such as in the Southern Ocean, the application of ${ }^{14} \mathrm{C}$ dating is limited.

Prior ${ }^{14} \mathrm{C}$ dating of near shore marine sediments demonstrated that the presence of old plant-derived terrigenous organic carbon often causes the ${ }^{14} \mathrm{C}$ age of total organic carbon (TOC) to be older than the stratigraphic age of the sediments (Eglinton et al. 1997; Jones and Gagnon 1994; Lyle et al. 1992). In contrast to these previous findings, we found that the ${ }^{14} \mathrm{C}$ age of TOC is systematically younger than the carbonate age from paired carbonate and TOC ${ }^{14} \mathrm{C}$ analyses made on three piston cores from opal-rich sediments in Southern Ocean (Table 1). The carbonate ${ }^{14} \mathrm{C}$ ages agreed very well with $\delta^{18} \mathrm{O}$ and $\%$ carbonate stratigraphy, indicating that the TOC ${ }^{14} \mathrm{C}$ analyses suffered from contamination by modern carbon. In addition to the paired carbonate and bulk TOC ${ }^{14} \mathrm{C}$ analyses, the presence and magnitude of modern carbon contamination was further established through analysis of radiocarbon-dead opal-rich marine sediment samples. Experiments have been designed to characterize the source of the modern carbon contamination and to reduce the contamination.

\footnotetext{
${ }^{1}$ Lamont-Doherty Earth Observatory and Department of Earth and Environmental Sciences, Columbia University, Palisades, New York 10964, USA

${ }^{2}$ Corresponding author. Present address: School of Earth and Environmental Sciences, Queens College, CUNY, Flushing, New York 11367, USA. Email: yan_zheng@qc.edu.

${ }^{3}$ School of Earth and Atmospheric Sciences, Georgia Institute of Technology, Atlanta, Georgia 30332, USA

${ }^{4}$ NSF-Arizona AMS Facility, University of Arizona, Tucson, Arizona 85721, USA

${ }^{5}$ NOSAMS, Woods Hole Oceanographic Institution, Woods Hole, Massachusetts 02543, USA

${ }^{6}$ Harvard University, Cambridge, Massachusetts 02138 and Lawrence Livermore National Laboratory, Livermore, California 94550, USA
} 
Table 1 Paired carbonate and bulk TOC radiocarbon analysis for opal-rich sediments from the Southern Ocean ${ }^{\mathrm{a}}$

\begin{tabular}{|c|c|c|c|c|c|c|c|c|c|}
\hline $\begin{array}{l}\text { Sample } \\
\text { description }\end{array}$ & $\mathrm{C}$ phase & $\begin{array}{c}{ }^{14} \mathrm{C} \text { age } \\
(\mathrm{yr})\end{array}$ & FM & $\mathrm{FM} \pm$ & $\begin{array}{c}\delta^{13} \mathrm{C} \\
(\% \circ \mathrm{PDB})\end{array}$ & $\begin{array}{c}\text { C mass } \\
(\mathrm{mg})\end{array}$ & $\begin{array}{c}\text { Modern C } \\
\text { inferred }^{b} \\
(\mu \mathrm{g})\end{array}$ & $\begin{array}{l}\text { NOAA } \\
\text { ANTnr }\end{array}$ & AA nr \\
\hline $\begin{array}{l}\text { PC RC } 13-254 \\
13 \mathrm{~cm}^{\mathrm{c}}\end{array}$ & TOC & 5524 & 0.5028 & 0.0037 & -22.00 & 1.16 & 144 & 35 & 15087 \\
\hline $\begin{array}{l}\text { PC RC 13-254 } \\
13 \mathrm{~cm}\end{array}$ & $\begin{array}{l}\text { Bulk } \\
\text { carb }\end{array}$ & 6734 & 0.4325 & 0.0032 & 0.25 & 1.09 & & 32 & 15084 \\
\hline $\begin{array}{l}\text { PC E11-2 } \\
32-34 \mathrm{~cm}^{\mathrm{c}}\end{array}$ & TOC & 7103 & 0.4130 & 0.0032 & -22.90 & 0.96 & 52 & 102 & 16215 \\
\hline $\begin{array}{l}\text { PC E11-2 } \\
32-34 \mathrm{~cm}\end{array}$ & $\begin{array}{l}\text { Bulk } \\
\text { carb }\end{array}$ & 7790 & 0.3792 & 0.0031 & 0.60 & 0.92 & & 53 & 15427 \\
\hline $\begin{array}{l}\text { PC E11-2 } \\
215-217 \mathrm{~cm}^{\mathrm{c}}\end{array}$ & TOC & 13285 & 0.1913 & 0.0030 & -22.30 & 1.21 & 205 & 103 & 16216 \\
\hline $\begin{array}{l}\text { PC E11-2 } \\
215-217 \mathrm{~cm}\end{array}$ & $\begin{array}{l}\text { pachy. } \\
\text { L }^{d}\end{array}$ & 29305 & 0.0260 & 0.0016 & -0.08 & 0.60 & & 113 & 16226 \\
\hline $\begin{array}{l}\text { PC E11-2 } \\
215-217 \mathrm{~cm}\end{array}$ & $\begin{array}{l}\text { Bulk } \\
\text { carb }\end{array}$ & 29507 & 0.0254 & 0.0013 & 0.30 & 1.01 & & 110 & 16223 \\
\hline $\begin{array}{l}\text { PC E33-22 } \\
76-78 \mathrm{~cm}\end{array}$ & TOC & 10791 & 0.2610 & 0.0024 & -21.49 & 0.85 & 204 & 38 & 15090 \\
\hline $\begin{array}{l}\text { PC E33-22 } \\
76-78 \mathrm{~cm}\end{array}$ & $\begin{array}{l}\text { Bulk } \\
\text { carb }\end{array}$ & 28776 & 0.0278 & 0.0013 & 0.40 & 1.04 & & 6 & 14837 \\
\hline
\end{tabular}

${ }^{a}$ All organic carbon radiocarbon ages have been normalized to $\delta^{13} \mathrm{C}$ of $-25 \% \circ$ and are relative to 1950

b Amount of modern $\mathrm{C}$ is calculated by mass balance using Equation (1)

${ }^{\mathrm{c}}$ Combustion tube contains quartz wool, which contributes maximum of $15 \mu \mathrm{g}$ of modern $\mathrm{C}$

${ }^{\mathrm{d}}$ Hand-picked shells of planktonic foraminifera species Neogloboquadrina pachyderma (sinistral coiling)

\section{MATERIALS AND METHODS}

For accelerator mass spectrometer (AMS) analysis of ${ }^{14} \mathrm{C}$, about $0.5-1 \mathrm{mg}$ of carbon was used. Combustion of organic carbon samples to $\mathrm{CO}_{2}$ was completed in evacuated $10 \mathrm{~mm}$ Quartz tubes containing $0.5 \mathrm{~g} \mathrm{CuO}$ and $100 \mathrm{mg} \mathrm{Ag}$ at $850{ }^{\circ} \mathrm{C}$ for $5 \mathrm{hr}$ (Pearson et al. 1998; Vogel et al. 1987). At the beginning of this study, quartz wool was inserted to each sample tube to prevent sample from popping up into the vacuum line during pumping (samples containing quartz wool were footnoted in all tables). Use of quartz wool during combustion was, however, later discontinued, as discussed in the results section. Quartz tubes and quartz wool used in this study were precombusted at $550{ }^{\circ} \mathrm{C}$ overnight prior to use. Graphitization of $\mathrm{CO}_{2}$ was completed by reduction with $\mathrm{H}_{2}$ over a metal catalyst, in this case Co (McNichol et al. 1992; Vogel et al. 1987). Materials used in this study and the acid pretreatment methods used prior to combustion are described in the following.

\section{MATERIALS}

Sources of carbon analyzed in this study include marine sediments (Table 2), Johnson Matthey Electronics (JME) graphite powder, a standard material for AMS analyses at the National Ocean Science AMS (NOSAMS) facility, and a Miocene age wood. Except for the paired carbonate and TOC ${ }^{14} \mathrm{C}$ analysis on samples from cores E11-2, E33-22, and RC13-254 (Table 1), all other organic carbon samples are known to be of an age great enough that they should be ${ }^{14} \mathrm{C}$-dead based on isotopic or biostratigraphy. 
Table 2 Sediment core location and date of recovery

\begin{tabular}{lcccc}
\hline Core & Latitude & Longitude & Water depth $(\mathrm{m})$ & Date core taken \\
\hline E11-2 & -56.073 & -115.093 & 3111 & Dec 1963 \\
E17-9 & -63.083 & -135.117 & 4851 & 1965 \\
E33-22 & -54.937 & -120.000 & 2745 & 1968 \\
RC13-254 & -48.567 & 5.133 & 3636 & Dec 1970 \\
RC13-259 & -53.883 & -4.933 & 2677 & Dec 1970 \\
RC13-271 & -51.983 & 4.517 & 3634 & Jan 1971 \\
TTN057-7-PC1 & -43.1912 & 11.728 & 4650 & Feb 1996 \\
TTN057-10-PC3 & -47.0968 & 5.916 & 4390 & Feb 1996 \\
TTN057-11-PC1 & -46.9321 & 6.257 & 4095 & Feb 1996 \\
TTN057-15-PC1 & -51.9031 & 4.517 & 3744 & Feb 1996 \\
EW9303 17JPC & 57.4839 & -37.573 & 3233 & 1993 \\
ODP Site 948 & 15.526 & -58.7323 & 4929 & June 1994 \\
\hline
\end{tabular}

Procedural-blank carbon introduced by sample acid pretreatment and combustion prior to graphitization was monitored through analysis of JME powder, Miocene-age wood, and Miocene-age clay rich sediment, ODP site 948 14X5 120-150 cm (Steiger 1997; Xu and Wise 1997).

The majority of the opal-rich, ${ }^{14} \mathrm{C}$-dead sediment samples were from the Southern Ocean, with one exception. Core EW 9303 17JPC was recovered in the North Atlantic Ocean and was sampled at a depth where a horizon of diatom opal-rich mat was determined to be older than marine isotopic stage $5 \mathrm{~d}$ (>100 ka BP) based on gray scale scanning (G Bond, personal communication 1998). This core had been refrigerated at $4{ }^{\circ} \mathrm{C}$ for over 2 years and was wet when sampled. Cores taken by R V Robert Conrad (RC13-254, RC13-259, and RC13-271) were from Lamont-Doherty's core repository maintained at room temperature and were dry after close to 30 years of storage. Cores taken by R V Eltanin (E11-2, E17-9, and E33-22) were stored at Florida State University's Antarctica Marine Geology Research Facility refrigerated at $4{ }^{\circ} \mathrm{C}$ for over 30 years and were wet when sampled. The E17-9 sample was from the bottom "flow in" sediments during piston coring and the "flow in" sample was kept in a refrigerator at Lamont for several years. Core catcher samples from Thomas Thompson Cruise TTN057 (-7PC, -10PC, -11PC, and -15PC; collected in February 1996) in the South Atlantic Ocean were kept frozen at $-4{ }^{\circ} \mathrm{C}$ at Lamont-Doherty except during the transportation period of about one week (Lloyd Burckle, personal communication 1996).

Bulk TOC samples and organic carbon in purified diatom opal were both utilized for ${ }^{14} \mathrm{C}$ analysis (see below for separation and treatment procedures). The rational for utilizing the diatom opal phase are twofold: 1) it has been demonstrated that diatom opal contains an intrinsic organic matrix (Swift and Wheeler 1992), and 2) this organic matrix is believed to be protected from external contamination and from diagenesis (Shemesh et al. 1993; Singer 1995). Therefore, an oxidative procedure was followed to eliminate all organic carbon except that which is protected inside the diatom opal frustule.

\section{Hydrochloric Acid Pretreatment for Bulk TOC Samples}

A standard protocol of using dilute hydrochloric acid (reagent grade, $1 \mathrm{~N}$ ) to acidify bulk sediment to yield TOC samples for ${ }^{14} \mathrm{C}$ analysis was adopted (Froelich 1980; McNichol et al. 1994). Samples were acidified, thoroughly rinsed with $18 \mathrm{M} \Omega$ water to neutral $\mathrm{pH}$, and finally oven or freeze-dried (All ${ }^{14} \mathrm{C}$ results with NOAA Ant number greater than 165 were freeze-dried). Pretreatment using $8 \%$ sulfurous acid (Verardo et al. 1990) or 5\% phosphoric acid left greater than $10 \%$ of the initial carbonate in the residue and was abandoned. 


\section{Hydrofluoric Acid pretreatment for Bulk TOC Samples}

As an attempt to remove contaminants from the surface of diatom opal, $1 \mathrm{~N} \mathrm{HF}$ (reagent grade) was used to attack carbonate and opal in bulk sediment at the same time, following a protocol similar to that of the $\mathrm{HCl}$ treatment described above. The total acid reaction time was 3 hours. Some samples were treated with a second HF treatment for an additional 24 hours before rinsing.

\section{Separation of Diatom Opal from Bulk Sediment}

Diatoms were purified from opal-rich sediment by a procedure similar to that described in Shemesh et al. (1988) with slight modifications (Mortlock et al. 1991). The final settling step was replaced by a sodium polytungstate $\left(3 \mathrm{Na}_{2} \mathrm{WO}_{4} \cdot 9 \mathrm{H}_{2} \mathrm{O}\right.$, by SOMETU, Germany) density separation (R Mortlock and $\mathrm{P} N$ Froelich, unpublished). The opal, with density ranging from 1.8 to $2 \mathrm{~g} / \mathrm{cm}^{3}$ (Hurd 1983), floated at the top of the heavy liquid (density $2.15 \mathrm{~g} / \mathrm{cm}^{3}$ ), whereas the clay sank to the bottom. Opal floating atop of heavy liquid was concentrated by centrifugation, rinsed with nanopure water (18 $\mathrm{M} \Omega$ ) and freeze-dried.

\section{Oxidative Cleaning of Diatom Opal}

Purified diatom opal was treated twice with concentrated nitric and perchloric acids (reagent grade, 1:1) at $65^{\circ} \mathrm{C}$ for 2 hours. Oxidized opal was then rinsed with $18 \mathrm{M} \Omega$ water and oven dried at $65^{\circ} \mathrm{C}$. This procedure is similar to that developed for ${ }^{13} \mathrm{C}$ analysis of diatom opal (Singer 1995), designed to remove all organic carbon except for that protected inside the opal matrix.

\section{RESULTS}

The "young age" obtained on TOC samples of opal-rich Southern Ocean sediment (Table 1) could be explained by modern carbon contamination either introduced during sample processing, i.e., procedural blank, or simply from contaminated sample, i.e., systematic blank. Therefore, it is critical to distinguish between these two potential sources of contamination. The procedural blank includes potential modern carbon contamination introduced during sample pretreatment prior to sample combustion, as well as the combustion, graphitization (McNichol et al. 1992; Pearson et al. 1998), handling and AMS machine blank (McNichol et al. 1994; Vogel et al. 1987). In the following, we first demonstrate that the combustion blank contributes at most $\sim 1 \mu \mathrm{g}$ of modern carbon and therefore it is a negligible source of modern carbon contamination. The procedural blank, including combustion, graphitization, handling, and accelerator background, contributes $\sim 2 \mu \mathrm{g}$ of modern carbon, comparable with an earlier indirect estimate of $2.2 \pm 1.1 \mu \mathrm{g}$ modern carbon (Vogel et al. 1987). We then quantify the magnitude of modern carbon contamination in various types of samples.

\section{Characterization of Combustion Blanks}

We quantified and characterized the combustion blank $\left(\mathrm{CO}_{2}\right.$ generated during the combustion process from $\mathrm{CuO}$ and $\mathrm{Ag}$, without loading any sample) at LDEO, parallel to the Pearson et al. (1998) study at NOSAMS (see Zheng 1999, for details). The amount of $\mathrm{CO}_{2}$ generated during combustion was quantified manometrically, and the existence of $\mathrm{CO}_{2}$ was confirmed by analysis on a Dycor Residual Gas Analyzer (RGA) at NOSAMS (McNichol et al. 1992). In addition, $\mathrm{CO}_{2}$ generated from multiple combustion blank samples was combined to prepare a "pooled blank" graphite target, containing $\sim 33 \mu \mathrm{g}$ of carbon.

Combustion blanks prepared at LDEO displayed characteristics (amount of $\mathrm{CO}_{2}$ generated, ${ }^{13} \mathrm{C}$ and ${ }^{14} \mathrm{C}$ ) similar to those prepared at NOSAMS (Pearson et al. 1998). LDEO combustion blanks aver- 
aged $1.21 \pm 0.53 \mu \mathrm{g} \mathrm{C}$. The "pooled" LDEO blank (33 $\mu \mathrm{g} \mathrm{C}$ ) had FM of $0.4011 \pm 0.012$, while the $\delta^{13} \mathrm{C}$ value of an individual LDEO blank was $-21.20 \%$.

Much larger combustion blanks $(14.5 \pm 3.3 \mu \mathrm{g} \mathrm{C})$ were obtained when quartz wool was included in the tubes. Adsorption of organic components onto the dynamic quartz wool surface is the most likely mechanism causing the elevated amount of carbon (Unger 1994). We therefore abandoned inserting quartz wool into quartz tube except for 10 samples prepared at the beginning of the study. For the majority of the samples, therefore, the combustion blank contributed at most $\sim 1 \mu \mathrm{g}$ of modern carbon.

\section{Procedural Blank Characteristics}

An independent evaluation of the part of the procedural blank that is common to all procedures (the combined blanks from combustion, graphitization and AMS machine background) was accomplished by analysis of combusted JME powder, which is a ${ }^{14} \mathrm{C}$-dead graphite powder. Procedural blanks display FM (fraction of modern carbon) values ranging from 0.0021 to 0.0116 , or ${ }^{14} \mathrm{C}$ ages of 35.8 to $48.6 \mathrm{ka}$ (Table 3). Only one of five measurements displayed an age younger than $40 \mathrm{ka}$ (Table 3). Except the one high FM value (AA 24235), other procedural blanks evaluated using JME powder were similar to the values obtained on un-combusted JME powder, which was pressed directly and run as a target, with a long term average FM of 0.002 measured at NOSAMS (Pearson et al. 1998).

Table 3 Radiocarbon results of ${ }^{14} \mathrm{C}$-dead procedural blank material

\begin{tabular}{|c|c|c|c|c|c|c|c|c|c|}
\hline $\begin{array}{l}\text { Sample } \\
\text { description }\end{array}$ & $\mathrm{C}$ phase & $\begin{array}{c}{ }^{14} \mathrm{C} \text { age } \\
(\mathrm{yr})\end{array}$ & $\mathrm{FM}$ & $\mathrm{FM} \pm$ & $\begin{array}{c}\delta^{13} \mathrm{C} \\
(\% \circ \mathrm{PDB})\end{array}$ & $\begin{array}{c}\text { C mass } \\
(\mathrm{mg})\end{array}$ & $\begin{array}{c}\text { Modern C } \\
\text { inferred }^{\mathrm{a}}(\mu \mathrm{g})\end{array}$ & $\begin{array}{l}\text { NOAA } \\
\text { ANT nr }\end{array}$ & AA nr \\
\hline \multicolumn{10}{|l|}{ ODP94814X5 } \\
\hline $\begin{array}{l}120-150 \mathrm{~cm} \\
\text { raw sed }\end{array}$ & Bulk & 38790 & 0.0080 & 0.0010 & -24.70 & - & & 87 & 15794 \\
\hline \multicolumn{10}{|l|}{ ODP94814X5 } \\
\hline \multicolumn{10}{|l|}{$120-150 \mathrm{~cm}$} \\
\hline $1 \mathrm{~N} \mathrm{HCl}^{\mathrm{b}}$ & TOC & 38119 & 0.0087 & 0.0011 & -26.90 & 2.06 & 18 & 88 & 15795 \\
\hline Miocene wood ${ }^{\mathrm{b}}$ & & 39691 & 0.0071 & 0.0012 & -21.85 & 0.91 & 6 & 37 & 15089 \\
\hline Miocene wood ${ }^{\mathrm{b}}$ & & 45996 & 0.0010 & 0.0011 & -22.84 & 3.23 & 3 & 39 & 15091 \\
\hline JME powder-1 & Graphite & 48600 & 0.0021 & 0.0007 & & 0.93 & 2 & 188 & NOSAMS \\
\hline JME powder-2 & Graphite & 35800 & 0.0116 & 0.0013 & -23.30 & 0.56 & 6 & 189 & 24235 \\
\hline JME powder-3 & Graphite & 42434 & 0.0051 & 0.0017 & & 0.639 & 3 & OC\#1097 & NOSAMS \\
\hline JME powder-4 & Graphite & 41043 & 0.0060 & 0.0012 & & 0.841 & 5 & OC\#1098 & NOSAMS \\
\hline JME powder-5 & Graphite & 42839 & 0.0048 & 0.0029 & & 0.458 & 2 & OC\#1099 & NOSAMS \\
\hline \multicolumn{10}{|l|}{ JME powder } \\
\hline $1 \mathrm{~N} \mathrm{HCl}-1$ & Graphite & 52800 & 0.0014 & 0.0002 & & 1.79 & 3 & 190 & NOSAMS \\
\hline \multicolumn{10}{|l|}{ JME powder } \\
\hline $1 \mathrm{~N} \mathrm{HCl}-2$ & Graphite & 49230 & 0.0022 & 0.0010 & -23.40 & 0.76 & 2 & 191 & 24236 \\
\hline
\end{tabular}

${ }^{a}$ Amount of modern $\mathrm{C}$ is calculated by mass balance using Equation (1)

${ }^{\mathrm{b}}$ Combustion tube contains quartz wool, which contributes up to $15 \mu \mathrm{g}$ of modern $\mathrm{C}$

The TOC procedural blank, following the method for treating TOC samples with $1 \mathrm{~N} \mathrm{HCl}$, was also evaluated using JME powder. Analysis of two JME powder samples produced FM values $(0.0012$ and 0.0022) lower than those obtained for JME powder samples that were not processed with $1 \mathrm{~N}$ $\mathrm{HCl}$ (Table 3). Processing with $1 \mathrm{~N} \mathrm{HCl}$ did not introduce any measurable amount of modern $\mathrm{C}$. 
An estimate of the amount of modern carbon contamination $\left(\mathrm{C}_{\mathrm{m}}\right)$ from all sources to JME powder samples can be obtained based on the following mass balance equation,

$$
C_{m}=C_{\text {sample }} \times \frac{F M_{\text {sample }}-F M_{\text {true }}}{F M_{m}-F M_{\text {true }}} .
$$

We assume that the FM value of the contaminants $\left(\mathrm{FM}_{\mathrm{m}}\right)$ is 1 . The carbon mass $\left(\mathrm{C}_{\text {Sample }}\right)$ in each sample is quantified manometrically at the AMS facility during purification prior to graphitization. When evaluating the ${ }^{14} \mathrm{C}$-dead samples, such as the JME powder here, the $\mathrm{FM}_{\text {true }}$ is taken as zero. Inserting into Equation (1) results for combusted JME powder and JME powder treated with $1 \mathrm{~N}$ $\mathrm{HCl}$, suggest that the amount modern carbon introduced ranged from 2 to $6 \mu \mathrm{g}$, but most often around $2 \mu \mathrm{g}$ (Table 3). This provides an upper limit for our procedural blank for TOC ages when quartz wool was not used.

\section{Extent of Modern Carbon Contamination}

${ }^{14} \mathrm{C}$ results presented in the introduction section on paired carbonate and TOC samples (Table 1) can be used to constrain the extent of modern carbon contamination using Equation (1). Assuming that the bulk TOC is contaminated by modern carbon $(\mathrm{FM}=1)$ and that the age obtained by planktonic foraminifera or bulk carbonate is the true age $\left(\mathrm{FM}_{\text {true }}\right)$, there is $50-200 \mu \mathrm{g}$, or 5-24\%, of modern carbon contamination to the bulk TOC samples (Table 1). It is evident that the modern carbon contamination in bulk TOC samples far exceeds the amount of modern carbon $(10-15 \mu \mathrm{g})$ in relevant TOC procedural blanks that contained quartz wool.

The extent of modern carbon contamination for radiocarbon-dead opal-rich sediment samples can also be constrained using mass balance calculations. Several TOC samples were taken from opalrich Southern Ocean sediment cores, from depth horizons that are older than $80 \mathrm{ka}$ based on ${ }^{18} \mathrm{O}$ and biological stratigraphy. In contrast to their known ages, these samples displayed ${ }^{14} \mathrm{C}$ ages between 15.3 and $33.1 \mathrm{ka}$, equivalent to $15-130 \mu \mathrm{g}$ of modern carbon contamination (Table 4). Here, again, the TOC procedural blank contribution of $2-6 \mu \mathrm{g}$ of modern $\mathrm{C}$ accounts for only a small fraction of the total modern $\mathrm{C}$.

Similar amounts of modern carbon contamination estimated by mass balance (Table 5) are found for TOC samples treated with $1 \mathrm{~N}$ HF. Partial opal dissolution occurred during $1 \mathrm{~N}$ HF attack, particularly for the samples treated for $28 \mathrm{hr}$. The initial weight of the samples was $\sim 500 \mathrm{mg}$. After the first $1 \mathrm{~N} \mathrm{HF}$ treatment for $3 \mathrm{hr}$, the weight decreased to $\sim 280 \mathrm{mg}$, and decreased further to only $\sim 100 \mathrm{mg}$ after the second $1 \mathrm{~N}$ HF treatment. However, despite the removal of a substantial amount of opal mass, samples treated with $1 \mathrm{~N} \mathrm{HF}$ were found to be contaminated by an amount of modern carbon no less than was found in samples treated with $1 \mathrm{~N} \mathrm{HCl}$ (Tables 4 and 5).

Diatom opal-intrinsic organic carbon samples, prepared following the purification method, followed by oxidation of unprotected organic matter using the $\mathrm{HClO}_{4}$ and $\mathrm{HNO}_{3}$ treatment, displayed ages younger than the TOC samples as a group, ranging from 9.2 to $17.8 \mathrm{ka}$ (Table 6). Mass balancederived modern $\mathrm{C}$ contamination ranged from 17 to $58 \mu \mathrm{g}$ (Table 6), which is within the range of modern $\mathrm{C}$ contamination found for the TOC samples treated by $\mathrm{HCl}$ (Table 4). However, because diatom opal samples generally had much smaller $\mathrm{C}$ mass than the TOC samples (Tables 4 and 6), the percentage of modern $\mathrm{C}$ contamination was larger for the diatom opal samples, ranging from $11 \%$ to $32 \%$ compared to $2-15 \%$ for TOC samples. 
Table 4 Radiocarbon results of ${ }^{14} \mathrm{C}$-dead TOC samples treated by $\mathrm{HCl}$

\begin{tabular}{|c|c|c|c|c|c|c|c|c|c|c|c|}
\hline Sample description & $\mathrm{C}$ phase & $\begin{array}{c}{ }^{14} \mathrm{C} \text { age } \\
(\mathrm{yr})\end{array}$ & FM & $\mathrm{FM} \pm$ & $\begin{array}{c}\delta^{13} \mathrm{C} \\
(\% \circ \mathrm{PDB})\end{array}$ & $\begin{array}{c}\text { C mass } \\
(\mathrm{mg})\end{array}$ & $\begin{array}{c}\text { Sample } \\
\text { mass (mg) }\end{array}$ & $\%$ Corg & $\begin{array}{l}\text { Modern } C^{a} \\
\quad(\mu \mathrm{g})\end{array}$ & $\begin{array}{l}\text { NOAA } \\
\text { ANT nr }\end{array}$ & AA nr \\
\hline E17-9 flow in raw sediment ${ }^{\mathrm{b}}$ & Bulk & 19,371 & 0.0897 & 0.0018 & -18.20 & 0.90 & 237 & 0.38 & 81 & 84 & 15791 \\
\hline E17-9 flow in. $1 \mathrm{~N} \mathrm{HCl}^{\mathrm{b}}$ & TOC & 15,262 & 0.1496 & 0.0019 & -21.85 & 0.89 & 300 & 0.30 & 133 & 36 & 15088 \\
\hline $\mathrm{RC} 13-259505 \mathrm{~cm} .1 \mathrm{~N} \mathrm{HCl}$ & TOC & 17,000 & 0.1203 & 0.0011 & -18.40 & 0.56 & - & & 67 & OS-5990 & NOSAMS \\
\hline E11-2 $1105-1106 \mathrm{~cm} .1 \mathrm{~N} \mathrm{HCl}^{\mathrm{c}}$ & TOC & 18,150 & 0.1047 & 0.0008 & -22.26 & 0.93 & - & & 97 & OS-5846 & NOSAMS \\
\hline TTN057-11-PC1cc ${ }^{\mathrm{d}} .1 \mathrm{~N} \mathrm{HCl}$ & TOC & 33,070 & 0.0163 & 0.0011 & - & 0.92 & 218 & 0.42 & 15 & 166 & 20718 \\
\hline TTN057-11-PC1cc. 1N HCl & TOC & 28,970 & 0.0271 & 0.0013 & -24.20 & 0.77 & 335 & 0.23 & 21 & 192 & 24237 \\
\hline TTN057-15-PC1cc. 1N HCl & TOC & 30,500 & 0.026 & 0.0018 & - & 0.75 & 213 & 0.35 & 20 & 167 & 20719 \\
\hline TTN057-15-PC1cc. 1N HCl & TOC & 26,370 & 0.0375 & 0.0013 & -21.30 & 0.93 & 355 & 0.26 & 35 & 193 & 24238 \\
\hline
\end{tabular}

${ }^{a}$ Amount of modern $\mathrm{C}$ is calculated by mass balance using Equation (1)

${ }^{\mathrm{b}}$ Combustion tube contains quartz wool, which contributes up to $15 \mu \mathrm{g}$ of modern $\mathrm{C}$

cRaw sediment sent to NOSAMS, treated by $1 \mathrm{~N} \mathrm{HCl}$ method, combusted and analyzed at NOSAMS

${ }^{\mathrm{d}} \mathrm{cc}=$ core catcher samples

Table 5 Radiocarbon results of ${ }^{14} \mathrm{C}$-dead TOC samples treated by HF

\begin{tabular}{|c|c|c|c|c|c|c|c|c|c|}
\hline Sample description & $\mathrm{C}$ phase & $\begin{array}{c}{ }^{14} \mathrm{C} \text { age } \\
(\mathrm{yr})\end{array}$ & FM & $\mathrm{FM} \pm$ & $\begin{array}{c}\delta^{13} \mathrm{C} \\
(\% \circ \mathrm{PDB})\end{array}$ & $\begin{array}{c}\mathrm{C} \text { mass } \\
(\mathrm{mg})\end{array}$ & $\begin{array}{l}\text { Modern } \\
\mathrm{C}^{\mathrm{a}}(\mu \mathrm{g})\end{array}$ & $\begin{array}{l}\text { NOAA } \\
\text { ANT nr }\end{array}$ & AA nr \\
\hline TTN057-11-PC1cc. IN HF $3 \mathrm{hr}$ & TOC & 28,435 & 0.0290 & 0.0014 & ND & 1.94 & 56 & 194 & 24239 \\
\hline TTN057-15-PC1cc. IN HF 3 hr & TOC & 27,240 & 0.0337 & 0.0013 & -21.50 & 1.07 & 36 & 195 & 24240 \\
\hline TTN057-11-PC1cc. IN HFx2 28 hr & TOC & 30,710 & 0.0219 & 0.0013 & -24.80 & 1.02 & 22 & 196 & 24241 \\
\hline TTN057-15-PC1cc. IN HFx2 28 hr & TOC & 24,020 & 0.0503 & 0.0013 & -23.00 & 0.9 & 45 & 197 & 24242 \\
\hline
\end{tabular}

${ }^{a}$ Amount of modern $\mathrm{C}$ is calculated by mass balance using Equation (1) 
Table 6 Radiocarbon results of ${ }^{14} \mathrm{C}$-dead diatom opal material ${ }^{\mathrm{a}}$

\begin{tabular}{|c|c|c|c|c|c|c|c|c|c|c|}
\hline $\begin{array}{l}\text { Sample } \\
\text { description }\end{array}$ & $\begin{array}{c}{ }^{14} \mathrm{C} \text { age } \\
(\mathrm{yr})\end{array}$ & FM & $\mathrm{FM} \pm$ & $\begin{array}{c}\delta^{13} \mathrm{C} \\
(\% 0 \\
\text { PDB) }\end{array}$ & $\begin{array}{c}\mathrm{C} \\
\text { mass } \\
(\mathrm{mg})\end{array}$ & $\begin{array}{c}\text { Sample } \\
\text { mass } \\
(\mathrm{mg})\end{array}$ & $\begin{array}{c}\% \\
\text { Corg }\end{array}$ & $\begin{array}{l}\text { Modern } \\
\mathrm{C}^{\mathrm{b}}(\mu \mathrm{g})\end{array}$ & $\begin{array}{l}\text { NOAA } \\
\text { ANT nr }\end{array}$ & AA nr \\
\hline E17-9 flow in & 14,121 & 0.1723 & 0.0041 & -23.80 & 0.16 & 46 & 0.35 & 28 & 85 & 15792 \\
\hline E17-9 $\mathrm{f}$ & 16,718 & 0.1248 & 0.0026 & -19.30 & 0.1 & & 0.15 & & & 16228 \\
\hline $\begin{array}{l}\text { EW930 } \\
470-47 \\
\text { RC13-2 }\end{array}$ & 9196 & 0.3183 & 0.0038 & -27.18 & 0.18 & 164 & 0.11 & 56 & 147 & 18207 \\
\hline $\begin{array}{l}\text { RC13-271 } \\
2410 \mathrm{~cm} \\
\text { RC13-271 }\end{array}$ & 17,820 & 0.1088 & 0.0022 & -20.02 & 0.37 & 204 & 0.18 & 40 & 148 & 18208 \\
\hline $2410 \mathrm{~cm} .2$ & 15,718 & 0.1413 & 0.0024 & -20.36 & 0.41 & 226 & 0.18 & 58 & 149 & 18209 \\
\hline & 22,841 & 0.0582 & 0.0018 & -19.48 & 0.27 & 295 & 0.09 & 16 & 150 & 18210 \\
\hline
\end{tabular}

${ }^{a}$ All samples are nitric and perchloric acid oxidized diatom opal

${ }^{\mathrm{b}}$ Amount of modern $\mathrm{C}$ is calculated by mass balance using Equation (1)

${ }^{\mathrm{c}} \mathrm{RC} 13-271$ is residual sample after vacuum step heating (Sample \#5, residual, Table 7)

Oxidation (using $\mathrm{HClO}_{4}$ and $\mathrm{HNO}_{3}$ ) of organic matter not protected within the diatom opal matrix failed to improve the apparent ${ }^{14} \mathrm{C}$ age of sediment affected by modern carbon contamination. Several aliquots of one sample (E17-9 FI "flow in"), which should have been ${ }^{14} \mathrm{C}$-dead based on its stratigraphic age, were analyzed by different procedures to test the effectiveness of the acid oxidation treatment in removing the modern-carbon contamination. Direct combustion of unprocessed sediment produced an age of $19.4 \mathrm{ka}$ (Table 4), while treating the sediment with $1 \mathrm{~N} \mathrm{HCl}$, following the standard procedure for TOC samples, produced an age of $15.2 \mathrm{ka}$ (Table 4). Purified diatom opal extracted from the sample was split into two aliquots which were then processed using the acid-oxidation treatment, yielding ages ( $14.1 \mathrm{ka}$ and $16.7 \mathrm{ka}$; Table 6 ) both older and younger than that of the TOC sample, and significantly younger than the age obtained for unprocessed sediment. Modern carbon contamination estimated for these replicate analyses is 28 and $17 \mu \mathrm{g} \mathrm{C}$, respectively (Table 6).

Subsequent analysis of acid-oxidized purified diatoms from two other cores (EW9303 and RC13271) confirmed the findings from E17-9. In each case, sediments were taken from depths corresponding to stratigraphic ages greater than $80 \mathrm{ka}$, yet these samples yielded apparent ${ }^{14} \mathrm{C}$ ages ranging from $9 \mathrm{ka}$ to $18 \mathrm{ka}$ (Table 6). Modern-carbon contamination of acid-cleaned purified diatoms, ranging from 17 to $58 \mu \mathrm{g}$ modern $\mathrm{C}$ (Table 6), was found to be common to all opal-rich sediments, whether from the Southern Ocean (E17-9 and RC13-271) or from the North Atlantic Ocean (EW9303).

\section{DISCUSSION}

\section{Sources of Modern Carbon Contamination}

\section{Modern Carbon Adsorbed to Diatom Opal Surface}

Our observations that quartz wool-containing combustion blanks have 15 times more $\mathrm{CO}_{2}$ than the "empty" combustion tubes suggest that silica surfaces may play an active role in absorbing carbon from the ambient environment. This is consistent with the known properties of amorphous and crystalline forms of silica, which are widely used as industrial adsorbents (Kenny and Sing 1994). The sorption of gases and vapors on silicate glass is also well known (Holland 1964). It has been demonstrated that due to strong hydrogen bonding between the hydroxylated surface of aerosilogel (a synthetic macro-porous silica with a uniform structure of the hydroxylated surface) and polarized 
organic molecules $\left(\mathrm{CH}_{3} \mathrm{COOC}_{2} \mathrm{H}_{5}, \mathrm{C}_{6} \mathrm{H}_{5} \mathrm{~N},\left(\mathrm{C}_{2} \mathrm{H}_{5}\right)_{3} \mathrm{~N}\right)$, these molecules cannot be desorbed from the aerosilogel by heating at temperatures ranging from 200 to $1100{ }^{\circ} \mathrm{C}$ under vacuum, followed by pumping (Curthoys et al. 1974; Kiselev et al. 1979). In other words, the adsorption process is found to be irreversible. Because diatom opal is composed of several amorphous forms of silica (Hurd 1983), it is plausible that adsorption of volatile organic molecules or atmospheric $\mathrm{CO}_{2}$ from the ambient environment could have caused a large amount of modern carbon contamination. This hypothesis is consistent with the observation that severe contamination is observed for diatom opal samples treated with strong oxidizing acids that would have eliminated other sources of modern C contamination, such as carbon fixed by chemosynthetic bacteria (see discussion later). We used a vacuum step heating experiment (described below) to provide further constraints on the characteristics of modern carbon contamination and to test the adsorption hypothesis.

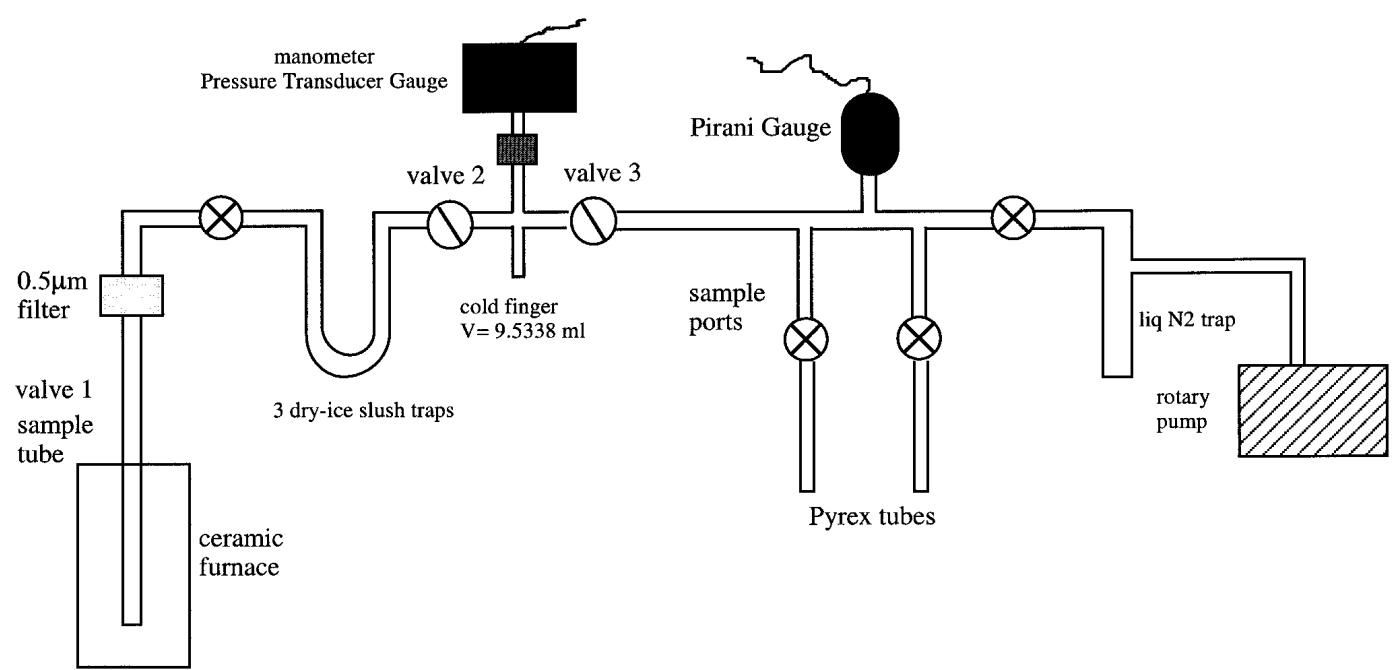

Figure 1 Schematic drawing of the vacuum line that was used to conduct the step heating experiment as described in the discussion section. The step heating process began with a starting temperature of $\sim 100$ or $\sim 200{ }^{\circ} \mathrm{C}$, measured by a Pt and $\mathrm{Ni}$ thermocouple at the top and the bottom of the ceramic furnace to yield the mean temperature of heating. The Pirani Gauge monitors the vacuum of the whole line. $\mathrm{CO}_{2}$ was quantified manometrically in a cold finger $(\mathrm{V}=9.5338 \mathrm{~mL})$, and then transferred to a Pyrex tube at liquid nitrogen temperature attached to one of the two available sample ports (only one of which is used for each sample). A liquid nitrogen trap was used between the vacuum line and rotary pump to trap oil vapor from the pump.

Two types of diatom opal sample, either untreated or treated with $\mathrm{HClO}_{4}$ and $\mathrm{HNO}_{3}$, were used in a step-heating experiment designed to extract and collect surface contaminants. Quartz tubes containing samples were evacuated on the system shown in Figure 1 above. After isolating the pump, each sample tube was heated with a ceramic furnace at sequentially increasing temperature in a series of steps (Table 7). The $\mathrm{CO}_{2}$ generated at each heating step was purified through three traps chilled by iso-propanol dry-ice slush, quantified manometrically, and flame sealed into a Pyrex tube. The majority of the gas samples collected in Pyrex tubes were analyzed by a coulometric method as well, which selectively determines $\mathrm{CO}_{2}$ with a detection limit of $\sim 1 \mu \mathrm{g}$. While most step-heating experiments were completed upon evaluating the amount of $\mathrm{CO}_{2}$ generated, samples of carbon dioxide generated by step heating at temperatures below $400{ }^{\circ} \mathrm{C}$ from sample \#5, RC13-271 $2410 \mathrm{~cm}$, were sent to NOSAMS for $\delta^{13} \mathrm{C}$ analysis (Table 7). The remainder of the sample in the quartz tube that had 
been treated by step-heating (sample \#5, "residual" in Table 7) was flame sealed, combusted and sent to the NSF AMS facility at Arizona for ${ }^{14} \mathrm{C}$ analysis (AA 18120, Table 7).

To compare results of different heating experiments, the quantity of $\mathrm{CO}_{2}$ released by vacuum heating at temperatures below $400{ }^{\circ} \mathrm{C}$ was summed and normalized to a sample size of $250 \mathrm{mg}$. The amount of $\mathrm{CO}_{2}$ released ( $100 \mu \mathrm{g} \mathrm{C} / 250 \mathrm{mg}$ sample; Table 7) is within the range of the amount of modern $\mathrm{C}$ contamination inferred by mass balance (see above). For example, the cumulative amount of $\mathrm{CO}_{2}$ released from acid oxidized E17-9 FI diatom opal ( $94 \mu \mathrm{g} / 250 \mathrm{mg}$; sample \#3, Table 7) is comparable to the amount released from untreated E17-9 FI diatom opal below $400{ }^{\circ} \mathrm{C}(92 \mu \mathrm{g} / 250 \mathrm{mg}$; sample \#2; Table 7).

The stable carbon isotopic composition was measured for each stage of $\mathrm{CO}_{2}$ released for the acidtreated opal sample from RC13-271 $2410 \mathrm{~cm}$ (Sample \#5; Table 7). The $\delta^{13} \mathrm{C}$ value of $\mathrm{CO}_{2}$ increased from -24.6 to $-14 \%$ as the heating temperature increased from 120 to $300{ }^{\circ} \mathrm{C}$ (Table 7). The stable isotope composition suggests that a large fraction of the $\mathrm{CO}_{2}$ released was originally present as

Table 7 Results of vacuum step heating experiments

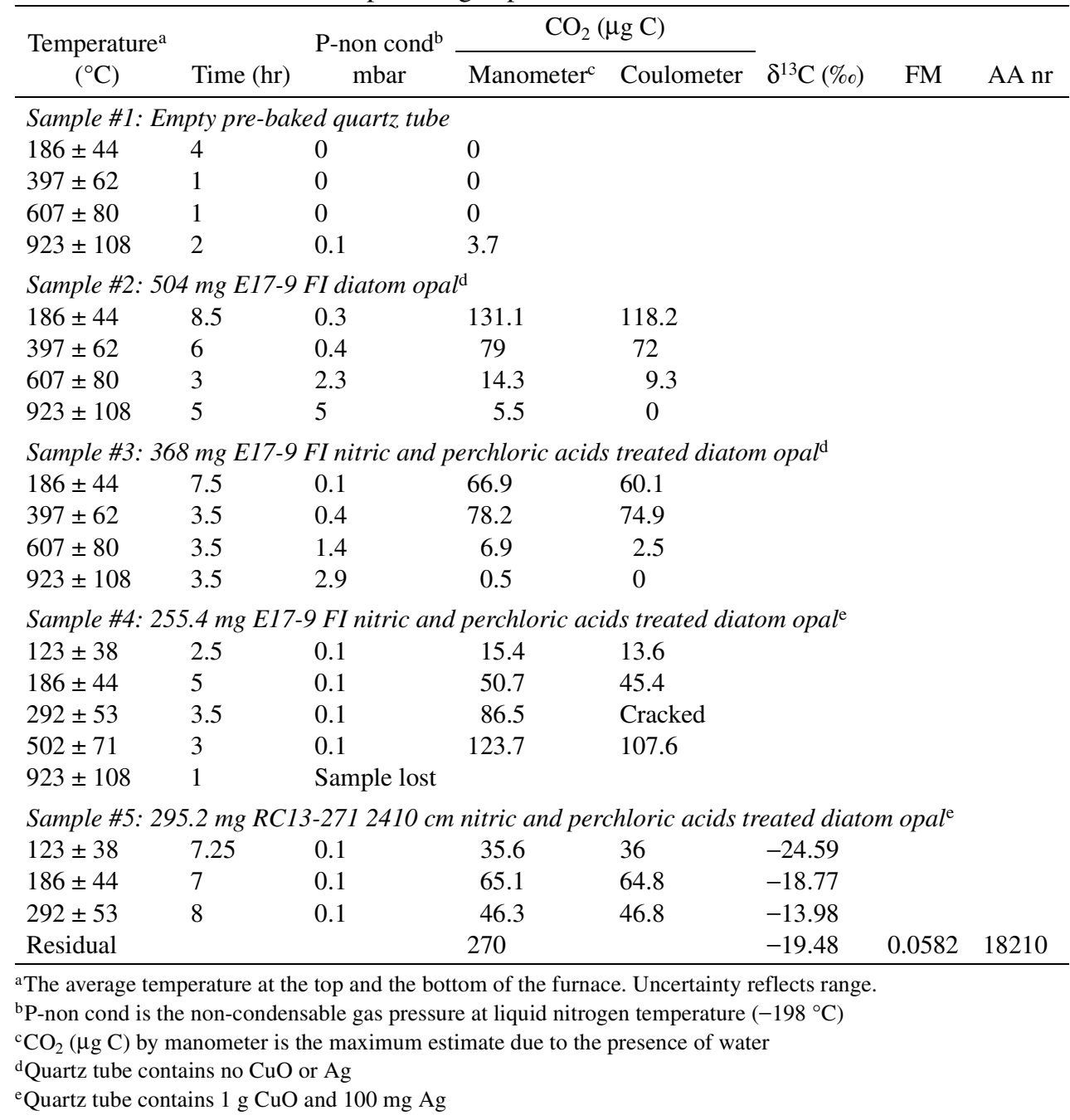


organic carbon, and was not entirely due to release of adsorbed atmospheric $\mathrm{CO}_{2}\left(\delta^{13} \mathrm{C}=-7 \%\right.$ ). The organic carbon that was converted to $\mathrm{CO}_{2}$ could have been amorphous organic matter (AOM) (Tyson 1995) adsorbed on the diatom opal, or opal-intrinsic organic carbon. However, it is not clear exactly what reaction, oxidation or pyrolysis, was responsible for transforming the organic carbon to $\mathrm{CO}_{2}$ gas. Pyrolysis of kerogens could start at temperature as low as $300{ }^{\circ} \mathrm{C}$ (Larter and Horsfield 1993). Pyrolysis of soil humics could start at temperature below $200{ }^{\circ} \mathrm{C}$ (Stevenson 1982). The fact the $\mathrm{CO}_{2}$ was produced without $\mathrm{CuO}$ at temperature below $400{ }^{\circ} \mathrm{C}$ (Sample \#2; Table 7) suggests that pyrolysis was the likely reaction. Alternatively, there may have been enough oxygen dispersed within the hydrous diatom opal to oxidize a significant fraction of organic carbon without $\mathrm{CuO}$.

The increase in the $\delta^{13} \mathrm{C}$ of evolved $\mathrm{CO}_{2}$ with increasing temperature (sample \#5; Table 7) indicates a change in source of released carbon. The trend of increasing $\delta^{13} \mathrm{C}$ with increasing temperature could be interpreted as an increased contribution of adsorbed atmospheric $\mathrm{CO}_{2}$, if the activation energy for desorption of atmospheric $\mathrm{CO}_{2}$ was higher than that required for the pyrolysis or oxidation of adsorbed AOM, or opal-intrinsic organic carbon. The amount of adsorbed atmospheric $\mathrm{CO}_{2}$ $\left(\delta^{13} \mathrm{C}=-7 \%\right.$ o) released during step heating can be estimated by mass balance. Assuming that the adsorbed $\mathrm{AOM}$ had a $\delta^{13} \mathrm{C}$ value of $-25 \%$ o, the amount of $\mathrm{CO}_{2}$ released was $\sim 0 \mu \mathrm{g} \mathrm{C}$ at $123{ }^{\circ} \mathrm{C}, 23 \mu \mathrm{g}$ $\mathrm{C}$ at $186{ }^{\circ} \mathrm{C}$, and $28 \mu \mathrm{g} \mathrm{C}$ at $292{ }^{\circ} \mathrm{C}$.

The FM of $\mathrm{CO}_{2}$ released during vacuum heating of acid-cleaned diatoms from RC13-271 was not measured directly, but can be estimated indirectly by mass balance to be 0.2480 . This estimate is derived using the ${ }^{14} \mathrm{C}$ value $(\mathrm{FM}=0.0582)$ of the "residual" of RC13-271 $2410 \mathrm{~cm}$ acid treated diatom opal after vacuum heating (Sample \#5; Table 7) and the average $(F M=0.1251)$ of the original bulk ${ }^{14} \mathrm{C}$ values $(\mathrm{FM}=0.1088 \& 0.1413)$ of $\mathrm{RC} 13-2712410 \mathrm{~cm}$ acid treated diatom opal (Table 6). The "residual" of RC13-271 $2410 \mathrm{~cm}$ acid treated diatom opal accounted for $65 \%$ of the carbon, while the released $\mathrm{CO}_{2}$ accounted for $35 \%$.

The most likely interpretation of the ${ }^{13} \mathrm{C}$ and ${ }^{14} \mathrm{C}$ isotopic characteristics of $\mathrm{CO}_{2}$ evolved during the vacuum heating is that $\mathrm{CO}_{2}$ was derived from a mixture of young and old amorphous organic molecules $(\mathrm{AOM})$ that displayed a range of ${ }^{13} \mathrm{C}$ characteristics, together with some adsorbed $\mathrm{CO}_{2}$. $\mathrm{A}$ complete mass balance of ${ }^{13} \mathrm{C}$ and ${ }^{14} \mathrm{C}$ cannot be reconstructed due to the following reasons: first, the $\mathrm{FM}$ and ${ }^{13} \mathrm{C}$ isotopic characteristics of $\mathrm{AOM}$ end member are unknown so we cannot tell if released $\mathrm{CO}_{2}$ comes partially from $\mathrm{AOM}$ or from a mixture of the $\mathrm{AOM}$ and adsorbed $\mathrm{CO}_{2}$; second, the $\mathrm{FM}$ value of each fraction of $\mathrm{CO}_{2}$ evolved during the vacuum step heating was not measured; third, whereas the original sample contained a total of $531 \mu \mathrm{g}$ of carbon based on its\% Corg value of 0.18 (Table 6) and sample weight of $295 \mathrm{mg}$, only $417 \mu \mathrm{g}$ of carbon $(\sim 80 \%)$ were recovered during the step heating. A composite $\delta^{13} \mathrm{C}$ value calculated by summing the contribution to $\delta^{13} \mathrm{C}$ by all fractions of released $\mathrm{CO}_{2}$ together with the $\delta^{13} \mathrm{C}$ of the "residual" is found to be $-19.2 \%$, which is slightly heavier than the measured original bulk $\delta^{13} \mathrm{C}$ of $-20.2 \%$ ( $(n=2)$ (Table 6), suggesting that the carbon that was un-accounted for $(\sim 22 \%)$ during step-heating should have a $\delta^{13} \mathrm{C}$ of $-23.7 \%$ o based on ${ }^{13} \mathrm{C}$ mass balance. Therefore, ${ }^{13} \mathrm{C}$ characteristics for the released $\mathrm{CO}_{2}$ and the un-accounted carbon is consistent with the AOM source.

The amount of $\mathrm{CO}_{2}$ released by vacuum step heating and the fact that young carbon was found in the released $\mathrm{CO}_{2}$ supports our hypothesis that adsorption of contaminants originating from the ambient atmosphere is an important mechanism contributing to the modern carbon contamination in diatom opal-rich samples. Furthermore, the ${ }^{13} \mathrm{C}$ and ${ }^{14} \mathrm{C}$ isotopic characteristics of $\mathrm{CO}_{2}$ released by heating in vacuum are similar to those of the combustion blank as discussed in the results section. This suggests that the contaminants for acid treated diatom opal could have a source similar to that of the combustion blank, possibly by adsorption of ambient atmospheric AOM to silica surfaces. 
Vacuum step heating of acid-oxidized diatom opal from RC13-271 reduced the amount of modern $\mathrm{C}$ contamination from $\sim 49 \mu \mathrm{g}$ (average of 40 and $58 \mu \mathrm{g}$; AA 18208 and 18209; Table 6) to $16 \mu \mathrm{g}$ (AA 18210; Table 6), and reduced the FM level by a factor of two from $\sim 0.1250$ (average of 0.1088 and 0.1413 ) to 0.0582 (Table 6). While this is a significant reduction, modern $\mathrm{C}$ contamination was not eliminated completely. We do not expect to fully eliminate the adsorbed contaminants because the adsorption of polarized organic molecules on amorphous silica surface has been found to be irreversible (Curthoys et al. 1974). Furthermore, a study of the kinetics of trichloroethylene (TCE) desorption from silica gel showed that desorption took two steps to complete, with the second slow step controlled by diffusion, where the level of TCE dropped from $2000 \mathrm{ppm}$ to $0.1 \mathrm{ppm}$ after about 5 days of continuous purging with nitrogen gas at $30^{\circ} \mathrm{C}$ (Werth and Reinhard 1997). We have not been able to find studies on kinetics of $\mathrm{CO}_{2}$ desorption from amorphous silica surface. If desorption kinetics of $\mathrm{CO}_{2}$ from amorphous silica surface also has a slow step, then the vacuum step heating experiment may simply have been too short (only $\sim 8 \mathrm{hr}$ in this study) to completely remove modern C contaminants.

\section{Chemosynthetic Bacteria as Modern Carbon Contamination Source?}

We have observed a preliminary, but very curious "storage effect", namely that the ${ }^{14} \mathrm{C}$ age of TOC samples appears to become younger with increasing period of sample storage. This tendency can be illustrated using a suite of ${ }^{14} \mathrm{C}$-dead TOC samples. Samples from cores RC13-259 and E11-2, stored for over 25 years (Table 2), displayed TOC ${ }^{14} \mathrm{C}$ ages of $\sim 18 \mathrm{ka}$ (Table 4 ). In contrast, TOC samples from TTN cores that had been stored for just over one year had ages of 26.4 and $28.9 \mathrm{ka}$ (AA 24237 and 24238; Table 4). Furthermore, these ages are both younger by $\sim 4$ ka than those of the same samples that were analyzed immediately after the samples were returned to Lamont from the coring expedition (AA 20718 and 20719; Table 4). The younger ages obtained from the second analysis of TTN samples (AA 24237 and 24238; Table 4) are not due to sample mishandling, because ${ }^{14} \mathrm{C}$ ages on TOC procedural blanks (1N HCl treated JME graphite powder; NOAA Ant 190 and 191; Table 3), which were processed together with the second set of TTN samples, were 49.2 and $52.8 \mathrm{ka}$.

Two mechanisms can be invoked to explain the observed "storage effect": 1) adsorption over time leading to enhanced level of modern carbon contamination, particularly for cores that were taken in mid-1960s and early 1970s when bomb ${ }^{14} \mathrm{C}$ content of the atmosphere was high with a peak FM value of $\sim 2$, and 2) chemosynthetic bacteria in the sediment core fixing carbon from atmosphere (Sirevag et al. 1977). Unfortunately, we cannot distinguish between the proposed two mechanisms, chemosynthesis or adsorption, with the available data.

\section{Reduction of Modern Carbon Contamination}

For $\mathrm{HClO}_{4}$ and $\mathrm{HNO}_{3}$ acid treated diatom opal, the mostly likely source of modern carbon contamination is from adsorption of $\mathrm{CO}_{2}$ or AOM from the ambient atmosphere. Two experiments were carried out in attempts to remove this adsorbed contamination. First, samples contained within heated tubes were exposed to oxygen in an effort to oxidize adsorbed organic molecules. In the second experiment, samples contained within heated tubes were exposed to water vapor, as well as oxygen, in an attempt to remove adsorbed contaminants $\left(\mathrm{CO}_{2}\right.$ or $\left.\mathrm{AOM}\right)$ by exchange with $\mathrm{H}_{2} \mathrm{O}$. But both experiments failed to reduce modern carbon contamination to a consistent background level.

In the first experiment each sample was loaded into a pre-baked open-ended quartz tube containing $1 \mathrm{~g}$ of $\mathrm{CuO}$ and $100 \mathrm{mg}$ of $\mathrm{Ag}$ and then flushed with oxygen at one of three temperatures $\left(25^{\circ} \mathrm{C}\right.$, $80{ }^{\circ} \mathrm{C}$, and $190{ }^{\circ} \mathrm{C}$ ) to oxidize organic matter adsorbed to opal surfaces and carry away $\mathrm{CO}_{2}$ in the $\mathrm{O}_{2}$ stream. Oxygen-treated samples were subsequently evacuated online in a set up similar to that of Figure 1 with the following modifications. First, the sample tube was placed horizontally and 
extended beyond the end of the ceramic furnace to connect through a valve to an ultra-pure oxygen supply. Second, a three-way valve was added between the $0.5 \mu \mathrm{m}$ filter (Figure 1) and the rest of the vacuum line, to direct the oxygen to vent during flushing and to switch to the vacuum line for evacuation. Then the sample was flame sealed at both ends and combusted at $850^{\circ} \mathrm{C}$. Three types of samples, TOC, diatom opal, and diatom opal treated with $\mathrm{HClO}_{4}$ and $\mathrm{HNO}_{3}$, all from a depth of $2410 \mathrm{~cm}$ in core $\mathrm{RC} 13-271$, were used in this experiment. The amount of carbon remaining after $\mathrm{O}_{2}$ oxidation decreased as temperature increased; at $190{ }^{\circ} \mathrm{C}$, only about $40 \%$ of the initial carbon remained.

Although $\mathrm{O}_{2}$ oxidation resulted in substantial carbon release (up to 60\%), it did not remove all the contaminants. The FM levels of two oxygen-treated acid-oxidized opal samples from RC13-271 $2410 \mathrm{~cm}$ were reduced to 0.0717 and 0.0428 , an improvement when compared to results obtained when aliquots of the acid-oxidized opal from RC13-271 $2410 \mathrm{~cm}$ were analyzed prior to oxygen treatment (FM levels of 0.1088 and 0.1413; AA 18208 and 18209, Table 6). This suggests that $\mathrm{O}_{2}$ removed part of the modern carbon contamination. However, the $\mathrm{FM}$ values achieved by $\mathrm{O}_{2}$ oxidation did not reach a constant level, making it difficult to correct for the blank for stratigraphic application.

The second experiment was similar to the first except that water vapor was added as an additional ingredient intended to displace adsorbed contaminants. Here, a single heating temperature $\left(105^{\circ} \mathrm{C}\right)$ was used. Addition of water vapor failed to reduce modern carbon contamination. FM values of all wet oxygen-treated TOC samples were comparable to, or higher than, the FM values for TOC samples treated with the oxygen alone, and for un-treated TOC samples (results not shown).

\section{CONCLUSIONS}

A significant (5-25\%) modern carbon contamination to diatom rich Southern Ocean sediment samples has been found to cause the ${ }^{14} \mathrm{C}$ age of bulk organic carbon and of opal-intrinsic organic carbon to be younger than its true age. Thorough evaluation of combustion and procedural blanks during preparation of organic carbon samples allows us to conclude that the modern carbon contamination occurred prior to the sample combustion and graphitization. Based on the low ${ }^{13} \mathrm{C}$ and the young $\mathrm{FM}$ values of $\mathrm{CO}_{2}$ evolved in the vacuum step heating experiment, we conclude that adsorption of contaminants from the ambient atmosphere $\left(\mathrm{CO}_{2}\right.$ and/or organic molecules containing young carbon) onto diatom opal surfaces contributes to the modern carbon contamination. Efforts to oxidize and/or displace the surface contaminants were unsuccessful. In addition, the modern carbon blank in diatom opal-rich samples treated with various methods is highly variable for unknown reasons; therefore, the prospects for making stratigraphically useful age determinations after making blank corrections is poor.

\section{ACKNOWLEDGMENTS}

The authors are grateful to many people who helped along the way. All the aspects of working with glass were taught by Guy Mathieu, and Guy was always there for yet another experiment. Rick Mortlock shared his expertise in diatom separation. Maggie Peacock and Pat Malone helped with sample preparation. Peter Schlosser, Martin Stute, and Jordan Clark shared their expertise in ${ }^{14} \mathrm{C}$ sample preparation and their vacuum lines. Inspiration to do GC-FID measurement of the "empty" combustion tubes came from David Chipman, who performed experiments in Taro Takahashi's lab, although the final measurement was made at Dan McCorkle's lab at WHOI. Dan also provided the special small volume vacuum line for blank quantification work. Peter deMenacol and Linda Baker kindly allowed modifications to be made on the LDEO sediment lab coulometer for $\mathrm{CO}_{2}$ gas measurement. Lloyd Burckle brought core catcher samples from the TTN cruise and helped prepare and analyze many diatom smear slides. Finally, Liz Osborne at NOSAMS provided technical guidance on preparing graph- 
ite targets for small samples, and $\mathrm{Al} \mathrm{Gagnon} \mathrm{provided} \mathrm{the} \mathrm{measurement} \mathrm{of} \delta^{13} \mathrm{C}$. This work is funded by a grants/cooperative agreement from the National Oceanic and Atmospheric Administration through award number UCSIO PO 10075411. The views expressed herein are those of the authors and do not necessarily reflect the views of NOAA or any of its sub-agencies. LDEO contribution 6247.

\section{REFERENCES}

Curthoys G, Davydov VY, Kiselev AV, Kiselev SA, Kuznetsov BV. 1974. Hydrogen bonding in adsorption on silica. Journal of Colloidal and Interface Science 48: $58-72$.

Eglinton TI, Benitez-Nelson BC, Pearson A, McNichol AP, Bauer JE, Druffel ERM. 1997. Variability in radiocarbon ages of individual organic compounds from marine sediments. Science 27:796-9.

Froelich PN. 1980. Analysis of organic carbon in marine sediments. Limnology and Oceanography 25:564-72.

Holland L. 1964. The properties of glass surfaces. New York: John Wiley \& Sons Inc.

Hurd DC. 1983. Physical and chemical properties of siliceous skeletons. In: Aston SR, editor. Silicon geochemistry and biogeochemistry. New York: Academic Press.

Jones GA, Gagnon AR. 1994. Radiocarbon chronology of Black Sea Sediments. Deep-Sea Research I 41: 531-57.

Kenny MB, Sing KSW. 1994. Adsorptive properties of porous silica. In: Bergna HE, editor. The colloid chemistry of silica. Advances in Chemistry Series 234. Washington DC: American Chemical Society. p 505-15.

Kiselev AV, Kuznetsov BV, Lanin SN. 1979. Adsorption of triethylamine and water vapor and the modification of silica surface by gaseous trimethylchlorosilane. Journal of Colloid and Interface Science 69:148-56.

Larter SR, Horsfield B. 1993. Determination of structural components of kerogens by the use of analytical pyrolysis methods. In: Engel MH, Macko SA, editors. Organic geochemistry: principles and applications. New York: Plenum Press. p 271-87.

Lyle M, Zahn R, Prahl F, Dymond J, Collier R, Pisias N, Suess E. 1992. Paleoproductivity and carbon burial across the California Current: the multitracers transect, $42^{\circ}$ N. Paleoceanography 7:251-72.

McNichol AP, Gagnon AR, Jones GA, Osborne EA. 1992. Illumination of a black box: analysis of gas composition during graphite target preparation. $\mathrm{Ra}$ diocarbon 34(3):321-9.

McNichol AP, Osborne EA, Gagnon AR, Fry B, Jones GA. 1994. TIC, TOC, DIC, DOC, PIC, POC - unique aspects in the preparation of oceanographic samples for ${ }^{14} \mathrm{C}$-AMS. Nuclear Instruments and Methods in Physics Research B92:162-5.

Mortlock RA, Charles CD, Froelich PN, Zibello MA, Saltzman J, Hays JD Burckle LH. 1991. Evidence for lower productivity in the Antarctic Ocean during the last glaciation. Nature 351:220-2.

Pearson A, McNichol AP, Schneider RJ, von Reden KF, Zheng Y. 1998. Microscale AMS ${ }^{14} \mathrm{C}$ measurement at NOSAMS. Radiocarbon 40(1):61-75.
Shemesh A, Mortlock RA, Smith RJ, Froelich PN. 1988. Determination of $\mathrm{Ge} / \mathrm{Si}$ in marine siliceous microfossils; separation, cleaning and dissolution of diatoms and Radiolaria. Marine Chemistry 25:305-23.

Shemesh A, Macko SA, Charles CD, Rau GH. 1993. Isotopic evidence for reduced productivity in the glacial Southern Ocean. Science 262:407-10.

Singer AJ, Shemesh A. 1995. Climatically linked carbon isotope variation during the past 430,000 years in Southern Ocean sediments. Paleoceanography 10: 171-7.

Sirevag R, Buchanan BB, Berry JA, Troughton JH. 1977. Mechanism of $\mathrm{CO}_{2}$ fixation in bacterial photosynthesis studied by carbon isotope fractionation technique. Arch. Microbiology 112:35-8.

Steiger T. 1997. Miocene radiolarian biostratigraphy of the décollement zone (Northern Barbados Ridge). In: Shipley TH, Ogawa Y, Blum P, Bahr JM, editors. Proceedings of the Ocean Drilling Program, Scientific Results 156:33-48.

Stevenson FJ. 1982. Humus chemistry: genesis, composition, reactions. New York: Wiley Inc. p 244-63.

Swift DM, Wheeler AP. 1992. Evidence for an organic matrix from diatom biosilica. Journal of Phycol. 28: 202-9.

Tyson RV. 1995. Sedimentary organic matter. London: Chapman \& Hall. p 249-59.

Unger KK. 1994. Surface structure of amorphous and crystalline porous silicas. In: Bergna $\mathrm{HE}$, editor. The colloid chemistry of silica. Advances in Chemistry Series 234. Washington DC: American Chemical Society. p 165-81.

Verardo D, Froelich PN, McIntyre A. 1990. Determination of organic carbon and nitrogen in marine sediments using the Carlo Erba NA-1500 Analyzer. DeepSea Research 37:157-65.

Vogel JS, Nelson DE, Southon JR. 1987. ${ }^{14} \mathrm{C}$ background levels in an accelerator mass spectrometry system. $R a$ diocarbon 29(3):323-33.

Werth CJ, Reinhard M. 1997. Effects of temperature on trichloroethylene desorption from silica gel and natural sediments. 2. Kinetics. Environment Science Technology 31:697-703.

$\mathrm{Xu}$ Y, Wise JSW. 1997. Calcareous nannofossils from Leg 156, Northern Barbados Ridge Complex. In: Shipley TH, Ogawa Y, Blum P, Bahr JM, editors. Proceedings of the Ocean Drilling Program, Scientific Results 156:49-56.

Zheng Y. 1999. The marine geochemistry of germanium, molybdenum and uranium: the sinks [PhD thesis]. New York: Columbia University. 336 p. 